\title{
Merkuri (Hg) di Permukaan Perairan Muara Sungai Banyuasin, Sumatera Selatan, Indonesia
}

\author{
Yulianto Suteja a, Anna Ida Sunaryo Purwiyanto b* , Fitri Agustriani ${ }^{\text {b }}$ \\ a Program Studi Ilmu Kelautan, Fakultas Kelautan dan Perikanan, Universitas Udayana, Kampus UNUD Bukit Jimbaran, Bali 80361, Indonesia \\ ${ }^{b}$ Jurusan Ilmu Kelautan, Fakultas Matematika dan Ilmu Pengetahuan Alam, Universitas Sriwijaya, Jl. Raya Palembang Prabumulih km 32 \\ Inderalaya, Ogan Ilir, Palembang, Sumatera Selatan, Indonesia \\ * Penulis koresponden. Tel.: +62-818-0364-9790 \\ Alamate-mail: anna.ida3@gmail.com
}

Diterima (received) 22 September 2018; disetujui (accepted) 23 Oktober 2018; tersedia secara online (available online) 24 Oktober 2018

\begin{abstract}
The purposes of this study were to determine the water quality, concentration and distribution of $\mathrm{Hg}$ in the surface water of Banyuasin river estuary. This research was conducted in June 2016 with 26 sampling stations. Measurement of in situ water quality was done using Conductivity Temperature Depth (CTD) multiparameter profiler while $\mathrm{Hg}$ metal was measured using Atomic Absorption Spectroscopy (AAS). The data obtained was interpolated by Inverse Distance Weighted (IDW) and then mapped spatially. The results showed that in general the water quality in Banyuasin river estuary still meets the seawater quality standards for marine biota based on KepMenLH no. 51 in 2004. The concentration of $\mathrm{Hg}$ in Banyuasin river estuary ranges from $0.001-0.032 \mathrm{mg} / \mathrm{L}$ with a distribution pattern that generally increases towards the ocean. The $\mathrm{Hg}$ concentration at the Banyuasin river estuary is on the maximum limit and exceeds the quality standard for marine biota.
\end{abstract}

Keywords: heavy metal; Mercury; Banyuasin river estuary

\begin{abstract}
Abstrak
Tujuan penelitian ini adalah mengetahui kualitas perairan, konsentrasi dan sebaran $\mathrm{Hg}$ di permukaan perairan Muara Sungai Banyuasin. Penelitian ini dilakukan pada Juni 2016 dengan 26 stasiun pengambilan sampel. Pengukuran kualitas perairan dilakukan secara insitu menggunakan Conductivity Temperature Depth (CTD) multiparameter profiler sedangkan logam Hg diukur menggunakan Atomic Absorption Spectroscopy (AAS). Data yang didapat diinterpolasi dengan metode Inverse Distance Weighted (IDW) dan kemudian dipetakan secara spasial. Hasil penelitian menunjukkan bahwa secara umum kualitas perairan di Muara Sungai Banyuasin masih memenuhi baku mutu air laut untuk biota laut berdasarkan KepMenLH no 51 Tahun 2004. konsentrasi logam Hg di perairan Muara Sungai Banyuasin berkisar antara 0.001-0.032 mg/L dengan pola distribusi yang secara umum semakin meningkat kearah lautan. Konsentrasi Hg di Muara Sungai Banyuasin rata-rata berada pada batas maksimal dan melampaui baku mutu untuk biota laut.
\end{abstract}

Kata Kunci: logam berat; merkuri; Muara Sungai Banyuasin

\section{Pendahuluan}

Logam merkuri atau $\mathrm{Hg}$ ("hydrargyrum") merupakan satu-satunya unsur logam yang memiliki bentuk fase cair pada suhu kamar $\left(25^{\circ} \mathrm{C}\right)$ dan sangat mudah menguap. Logam $\mathrm{Hg}$ selama ini dikenal dengan logam yang sangat berbahaya, karena tingginya toksisitas yang ditimbulkan bila masuk ke dalam tubuh organisme (Neustadt dan
Pieczenik, 2007; Achparaki et al., 2012; Chen et al., 2012). Secara alami, semua logam berat (termasuk $\mathrm{Hg}$ ) bersifat mudah berikatan dan mengendap di perairan, sehingga dengan mudah masuk ke tubuh organisme dan berasosiasi dengan rantai makanan (Purnawan et al., 2013; Suteja dan Dirgayusa, 2018). Logam $\mathrm{Hg}$ yang terbuang ke perairan akan mengalami transformasi bentuk kimia akibat aktivitas mikroorganisme (Liu et al., 2018). 
Transformasi inilah yang kemudian mengakibatkan logam $\mathrm{Hg}$ dapat terserap dengan mudah ke dalam tubuh organisme (Jaishankar et al., 2014). Bahkan Lasut (2009) membuktikan bahwa terjadi biomagnefikasi logam $\mathrm{Hg}$ dari fitoplankton hingga ke konsumen 2. Hutagalung (1985) menjelaskan secara terperinci, bahwa organ tubuh yang dirusak oleh logam $\mathrm{Hg}$ akan sangat bergantung pada bentuk senyawa $\mathrm{Hg}$ yang masuk ke dalam tubuh. Bila berupa uap akan merusak paru-paru, berupa senyawa anorganik akan merusak ginjal dan hati, berupa metil raksa akan merusak sel otak dan menerobos dinding plasenta, sehingga ibu yang sedang hamil kemungkinan akan melahirkan anak yang cacat.

Walapun bersifat toksik dan berpotensi bioakumulatif, logam $\mathrm{Hg}$ juga banyak digunakan untuk keperluan manusia. Goldwater \& Clarkson (1972) dalam Hutagalung (1985) menjelaskan bahwa sejak permulaan abad ke 4, logam $\mathrm{Hg}$ telah digunakan manusia untuk pembuatan obat dan cat. Bahkan penggunaan logam $\mathrm{Hg}$ masih terus dilakukan dalam industri (pulp dan kertas), dan bahkan untuk pertanian (pembuatan biosida, terutama untuk fungisida dan bakterisida). Ditambahkan oleh Zhang dan Wong (2007) sumber utama dari pencemaran $\mathrm{Hg}$ adalah dari aktivitas pertanian, pertambangan, pembuangan air limbah kota dan Industri. Selain itu aktivitas pembakaran batubara memberikan sumbangan terhadap pencemaran logam $\mathrm{Hg}$ (Ansyori, 2011). Aktivitas manusia tersebut tentu saja akan berdampak pada peningkatan konsentrasi logam Hg di alam.
Selain dipengaruhi oleh sumbernya, kosentrasi logam berat merkuri sangat tergantung dari kualitas fisika, kima dan biologis perairan (Ullrich et al., 2001). Sebagai contoh, secara fisika konsentrasi $\mathrm{Hg}$ dalam perairan cenderung lebih tinggi pada suhu rendah dibandingkan suhu tinggi (Schuhmacher et al., 1993). Secara kimia, inorganic $\mathrm{Hg}$ umumnya akan banyak terakumulasi pada kondisi salinitas rendah (Laporte et al., 1997) dan konsentrasi merkuri akan meningkat dengan adanya material organik terlarut di kolom perairan (Ravichandran, 2004). Selain itu, adanya bakteri dalam perairan dapat menurunkan konsentrasi $\mathrm{Hg}$ melalui proses bioremediasi (Barkay et al., 1997; Lutfi et al., 2018).

Muara Sungai Banyuasin merupakan muara dari dua sungai (Sungai Banyuasin dan Sungai Lalan) di provinsi Sumatera Selatan (Purwiyanto, 2015). Sungai ini secara umum melewati Kabupaten Banyuasin dan Musi Banyuasin. Sumber pencemaran Hg pada Sungai Banyuasin diduga kuat berasal dari berbagai aktifitas. Sumber pencemaran $\mathrm{Hg}$ yang paling besar diduga berasal dari aktifitas pertanian dan perkebunan. Menurut Badan Pusat Statistik (BPS) Sumatera Selatan (2016), Kabuapaten Banyuasin dan Musi Banyuasin memiliki luas total lahan pertanian padi dan perkebunan masing-masing 298.231 ha dan 500.212 ha. Sumber pencemaran lainnya berasal dari aktifitas penambangan batubara. Menurut BPS Sumatera Selatan (2016), produksi batubara semakin meningkat dari Tahun 2012 ke Tahun 2015. Proses transportasi batubara di Sumatera Selatan yang masih dominan melalui sungai

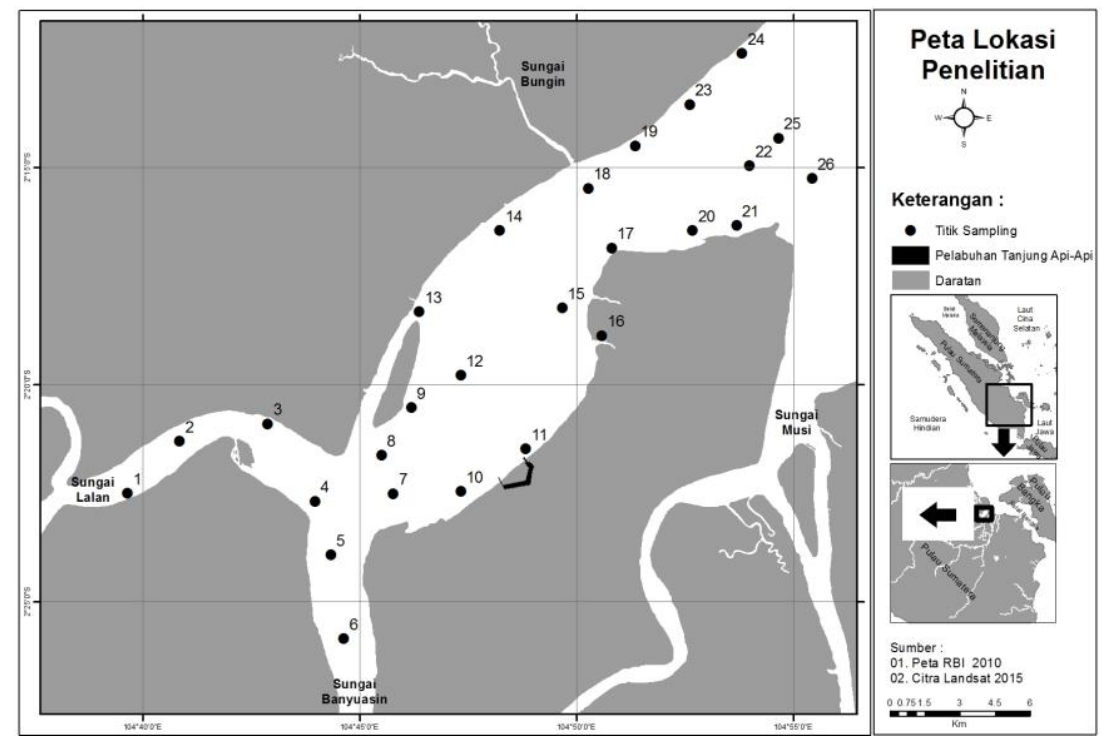

Gambar 1. Peta lokasi penelitian 
(Pratiwi, 2017) dan proses penyimpanan sementara (stockpile) batubara disepanjang sungai juga memberikan sumbangan terhadap logam berat di perairan sungai (Purwiyanto, 2015; Putri et al., 2016). Adanya pabrik PT Pupuk Sriwidjaya yang menggunakan batubara sebagai bahan bakar (Hazliansyah, 2012) juga dapat menjadi sumber kuat pencemaran $\mathrm{Hg}$ diperairan.

Kualitas perairan Muara Sungai Banyuasin yang fluktuatif diduga kuat juga mempengaruhi Konsentrasi $\mathrm{Hg}$. Hasil penelitian yang dilakukan oleh Ulqodry et al. (2010) menunjukkan adanya perbedaan karakteristik perairan Muara Sungai Banyuasin pada zona laut, muara dan sungai. Ditambahkan oleh Surbakti et al. (2014) bahwa, salinitas air laut melakukan intrusi yang cukup jauh ke arah hulu.

Tingkat toksisitas, adanya sumber pencemaran, dan kualitas perairan yang fluktuatif di daerah Muara Sungai Banyuasin mengakibatkan perlunya monitoring $\mathrm{Hg}$. Apalagi mengingat penggunaan daerah Muara Sungai Banyuasin sebagai zona tangkapan ikan bagi nelayan sekitar. Penelitian ini bertujuan mengetahui kualitas perairan, konsentrasi dan pola sebaran logam $\mathrm{Hg}$ di permukaan perairan Muara Sungai Banyuasin.

\section{Metode Penelitian}

Penelitian dilakukan pada bulan Juni 2016 di Muara Sungai Banyuasin. Pengambilan titik stasiun dilakukan dengan menggunakan metode purposive sampling, yaitu 26 stasiun yang mewakili keseluruhan wilayah perairan Muara Banyuasin (Gambar 1). Sampel air yang digunakan untuk analisis logam $\mathrm{Hg}$ adalah air permukaan (50 $\mathrm{cm}$ ) sesuai dengan Bahnasawy et al. (2011). Metode pengambilan sampel dilakukan dengan cara diambil langsung menggunakan botol sampel dan kemudian dimasukkan ke dalam cool box (Tilaar, 2014). Hal ini dilakukan untuk menghindari adanya kontaminasi pada sampel air. Sampelsampel tersebut kemudian dibawa ke laboratorium untuk dilakukan analisis logam $\mathrm{Hg}$. Analisis $\mathrm{Hg}$ dilakukan dengan menggunakan AAS. Selain melakukan pengambilan sampel, juga dilakukan pengukuran parameter kualitas perairan secara insitu ( $\mathrm{pH}$, suhu, Oksigen Terlarut, dan salinitas). Parameter perairan tersebut diambil dengan menggunakan Valeport MIDAS CTD multiparameter profiler. Hasil pengukuran insitu maupun laboratorium dipetakan secara spasial dengan melakukan interpolasi IDW. Menurut Pramono (2008) interpolasi IDW memiliki nilai interpolasi yang lebih mendekati nilai maksimal dan minimal sampel data sehingga lebih akurat dibandingkan interpolasi kriging. Data penelitian kemudian dibandingkan dengan baku mutu sesuai Keputusan Menteri Lingkungan Hidup (KepMenLH) No 51 Tahun 2004.

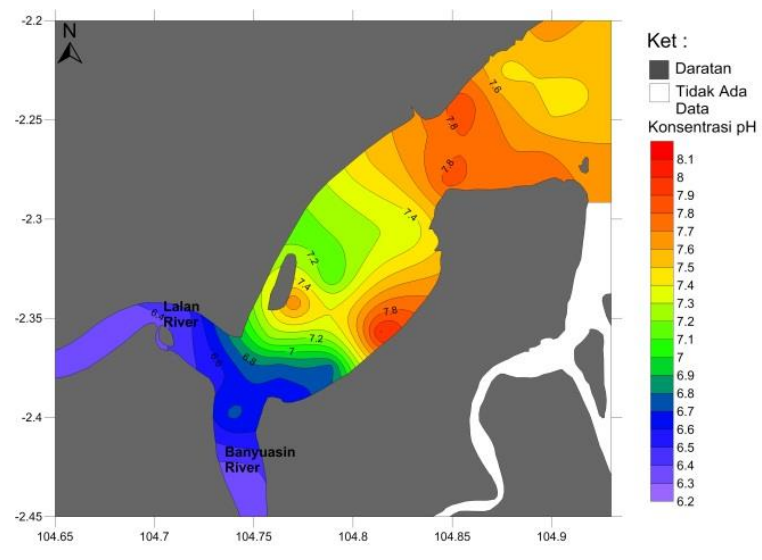

Gambar 2. Sebaran $\mathrm{pH}$ di permukaan perairan Muara Sungai Banyuasin.

\section{Hasil dan Pembahasan}

\subsection{Parameter Kualitas Perairan}

\subsection{1. $\mathrm{pH}$}

Kisaran $\mathrm{pH}$ yang diperoleh pada penelitian adalah 6.2-8.1 (Gambar 2). Sebaran $\mathrm{pH}$ di perairan menunjukkan bahwa semakin ke arah laut, nilai $\mathrm{pH}$ semakin meningkat. Hal ini sesuai dengan Simanjuntak (2009) dan Sembiring et al. (2012) yang mengemukakan bahwa pada umumnya $\mathrm{pH}$ air laut adalah basa karena semakin jauh dari daratan, nilai salinitas akan mengalami peningkatan yang diikuti dengan meningkatnya pH. $\mathrm{pH}$ terendah diperoleh di badan Sungai Lalan dan Sungai Banyuasin, sedangkan $\mathrm{pH}$ tertinggi diperoleh di sisi timur muara (dekat dengan laut). Nilai terendah $\mathrm{pH}$ yang diperoleh pada penelitian ini lebih rendah dibandingkan $\mathrm{pH}$ pada penelitian yang dilakukan Zulhaniarta et al. (2015), Prasetio et al. (2016), dan Purwiyanto et al. (2018) di lokasi yang sama. Namun demikian, pola sebaran $\mathrm{pH}$ sesuai dengan Purwiyanto et al. (2018), dimana pH tertinggi dan $\mathrm{pH}$ terendah diperoleh pada daerah yang sama. Nilai pH di Muara Sungai Banyuasin ini masih memenuhi KepMenLH no 51 Tahun 2004 tentang standar baku mutu air laut bagi biota laut yaitu masih dalam rentang 7-8,5. 


\subsubsection{Oksigen Terlarut (Dissolved Oxygen/DO)}

Perairan Muara Sungai Banyuasin memiliki DO antara 8.3-9.9 ppm dengan sebaran DO yang makin meningkat ke arah muara (Gambar 3). Pola peningkatan pada sebaran ini diduga karena proses difusi oksigen dari udara ke perairan pada daerah mulut muara yang menuju laut semakin tinggi. Hal ini didukung oleh Kangkan (2006) yang mengemukakan bahwa daerah yang terbuka akan memudahkan difusi oksigen yang terjadi antara udara dan perairan. Nilai DO yang didapatkan pada kajian ini lebih besar dibandingkan penelitian terdahulu di lokasi yang sama, yaitu berkisar antara 4.3-7.8 ppm (Zulhaniarta et al., 2015; Prasetio et al., 2016; Barus, 2017). Hal ini diduga karena adanya perbedaan faktor eksternal yang terjadi saat pengukuran dilakukan dengan pengukuran saat penelitian yang lain. Simanjutak (2009) mengemukakan factor-faktor yang mempearuhi konsentrasi DO di perairan, yaitu temperatur, kadar garam (salinitas), tekanan atmosfir, arus, kelimpahan fitoplankton, proses turbulensi air oleh angin dan tingkat kejenuhan oksigen sekitarnya. Nilai DO yang diperoleh saat penelitian masih sesuai dengan KepMenLH no 51 Tahun 2004 untuk biota laut yang memeiliki nilai diatas $5 \mathrm{mg} /$ L.Paragraf teks utama (Lillesand et al., 2004).

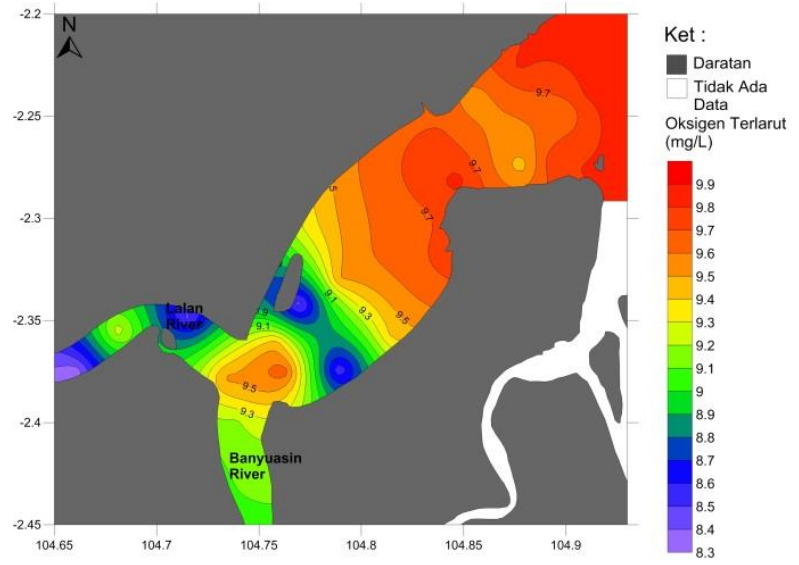

Gambar 3. Sebaran DO di permukaan perairan Muara Sungai Banyuasin.

\subsubsection{Suhu}

Suhu atau temperatur perairan Muara Sungai Banyuasin berkisar antara 29.55-30.6 oC (Gambar 4). Adanya kisaran nilai suhu disebabkan karena adanya perbedaan waktu pengukuran. Perbedaan waktu akan menyebabkan perbedaan penetrasi sinar matahari ke dalam kolom perairan, sehingga memberikan suhu yang berbeda pula. Selain itu, kondisi cuaca saat pengambilan sampel juga mempengaruhi nilai suhu yang diperoleh (Purwiyanto et al., 2018). Berdasarkan KepMenLH no 51 Tahun 2004, suhu yang diperoleh dari hasil penelitian di Muara Sungai Banyuasin masih berada dalam rentang baku mutu air laut yang diperbolehkan untuk biota laut.

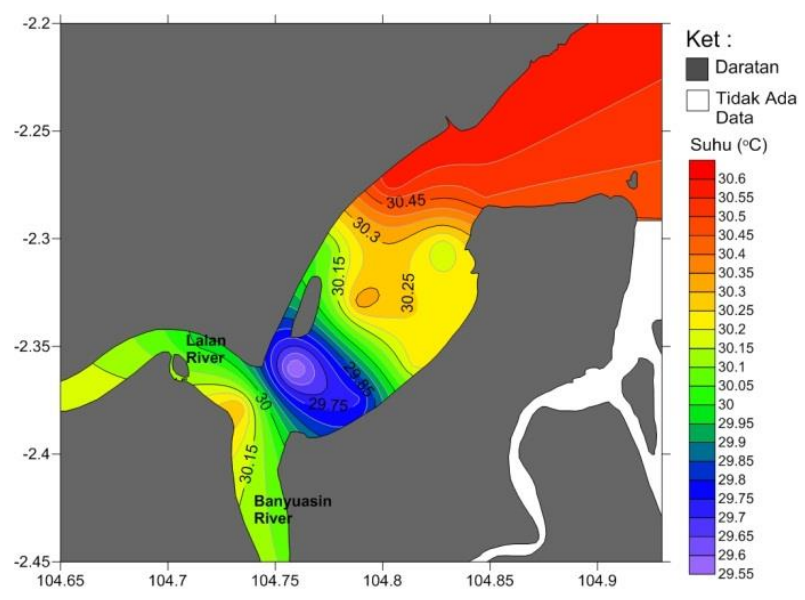

Gambar 4. Sebaran suhu di permukaan perairan Muara Sungai Banyuasin.

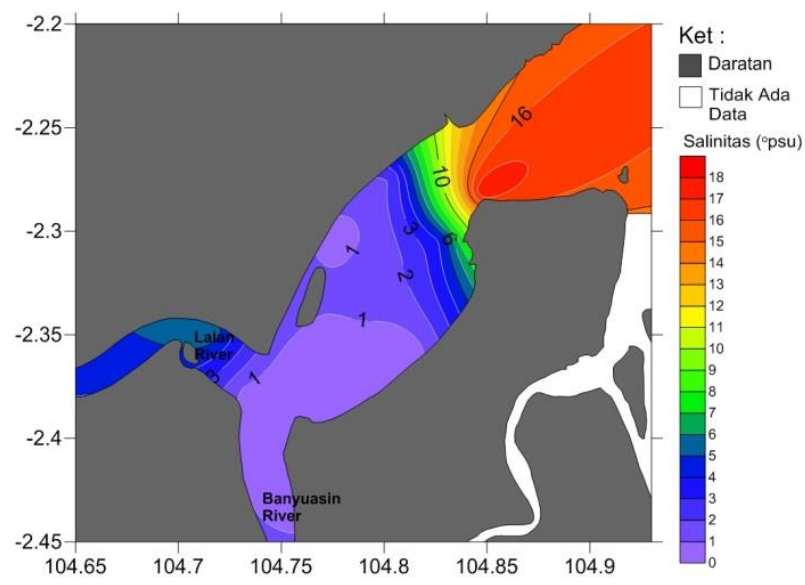

Gambar 5. Sebaran salinitas di permukaan perairan Muara Sungai Banyuasin

\subsubsection{Salinitas}

Salinitas air yang didapatkan di muara sungai berkisar antara 0-18 PSU (Gambar 5). Pola distribusi salinitas menunjukkan bahwa salinitas semakin tinggi semakin jauh dari sungai. Salinitas tertinggi ditemukan didaerah dekat lautan dan salinitas terendah ditemukan pada ke arah Sungai Lalan dan Sungai Banyuasin. Nilai salinitas ini 
lebih rendah dengan yang didapatkan oleh Surbakti et al. (2014) yang berkisar 24-37 psu. Rendahnya salinitas yang didapatkan pada penelitian ini disebabkan karena proses pengukuran yang dilakukan saat kondisi air surut sehingga air tawar mendominasi di badan muara. Ditambahkan oleh Supriadi (2001) bahwa proses pasang surut dan musim merupakan faktor utama yang mempengaruhi salinitas di daerah muara sungai. Nilai salinitas di Muara Sungai Banyuasin masih dalam kisaran normal (alami) sehingga masih layak untuk kehidupan biota laut berdasarkan KepMenLH no 51 Tahun 2004.

\subsection{Logam Merkuri ( $\mathrm{Hg})$}

Hasil pengukuran Hg di Muara Sungai Banyuasin menunjukkan konsentrasi bersifat fluktuafif (Gambar 6). Kandungan Hg didapatkan berkisar antara 0,001 - 0,032 $\mathrm{mg} / \mathrm{L}$ dengan kosentrasi ratarata $0,05 \mathrm{mg} / \mathrm{L}$. Pola distribusi $\mathrm{Hg}$ tinggi di bagian mulut muara yang berhadapan langsung dengan laut, dan rendah pada bagian mulut sungai. Hasil yang diperoleh secara umum memiliki pola yang sama dengan Barus (2017), dimana kandungan Hg tinggi pada mulut muara yang berhadapan dengan laut. Adanya kandungan $\mathrm{Hg}$ di Muara Sungai Banyuasin diduga disebabkan oleh banyaknya aktfitas pertanian, perkebunan, pertambangan dan rumah tangga pada hulu Sungai Lalan dan Sungai Banyuasin yang diduga memberikan buangan limbah Hg. Adanya masukan dari sungai ini dibuktikan dengan sebaran pH (Gambar 2) dan Salinitas (gambar 5) yang rendah pada daerah dekat mulut sungai. Tingginya tingkat pertanian, perkebunan dan pertambangan di Kabupaten Banyuasin ditunjukkan dengan semakin meningkatnya konversi hutan rawa primer untuk dijadikan sebagai lahan monokultur, lahan intensif, (pertanian, perkebunan sawit dan karet) dan lahan penambangan batubara (Affandi et al., 2016). Sumber pencemaran lainnya adalah adanya stockpile batubara yang berada di sekitar kawasan sisi darat Muara Sungai Banyuasi (Kawasan Tanjung Api) (Rusdianasari, 2015). Logam Hg merupakan salah satu kandungan utama dalam batubara (Toole-O'Neil et al., 1999).

Keberadaan $\mathrm{Hg}$ pada bagian muara yang berdekatan dengan laut diduga dipengaruhi oleh kondisi fisika kimia perairan sendiri. Selain itu, sifat $\mathrm{Hg}$ yang pada umumnya berikatan dengan mineral dan mudah berikatan dengan klorin, sulfur, oksigen dan karbon, mengakibatkan secara alami logam $\mathrm{Hg}$ akan dijumpai di alam meski dalam jumlah yang kecil (Suyanto et al., 2010). Tingginya kosentrasi logam berat dekat mulut muara diduga kuat juga disebabkan oleh sifat logam berat yang memiliki tingkat kelarutan tinggi, susah didegradasi dan mudah terakumulasi di kolom perairan (Kotas dan Stasicka, 2000; Pawlikowski et al., 2006; Biswas et al., 2017).

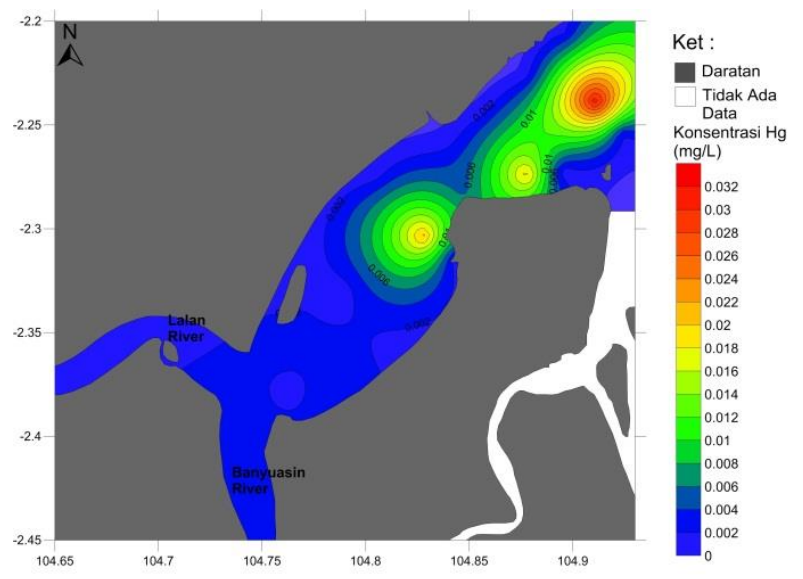

Gambar 6. Sebaran Hg di permukaan perairan Muara Sungai Banyuasin

Pola sebaran $\mathrm{Hg}$ di perairan Muara Sungai Banyuasin cenderung tidak memiliki pola yang sama dengan pola distribusi suhu perairan. Hal ini diduga karena fluktuasi suhu harian yang rendah. Dijelaskan oleh Schuhmacher et al. (1993) bahwa pengaruh suhu akan signifikan terhadap konsentrasi Hg pada saat rentang suhunya sangat tinggi, misalkan antara musim dingin dan musim panas.

Rendahnya kosentrasi $\mathrm{Hg}$ yang ditemukan pada Muara Sungai Banyuasin diduga kuat juga disebabkan oleh kondisi lingkungan perairan yang oksik (lebih dari $4 \mathrm{mg} / \mathrm{L}$ ) (Gambar 3). Dijelaskan oleh Regnell et al. (1996), bahwa Hg akan cenderung banyak terlarut di dalam kondisi miskin atau tidak ada oksigen (anoksik).

Nilai logam $\mathrm{Hg}$ yang ditemukan di perairan Muara Sungai Banyuasin memiliki nilai yang lebih besar dibandingkan di Muara Sungai Tondano yang berkisar antara 0.000231-0.000268 mg/L (Tilaar, 2014). Namun lebih kecil dibandingkan Hg pada perairan Pesisir Wonorejo, Pantai Timur Surabaya yang berkisar antar 0.015-0.017 mg/L (Sari et al., 2017). Kandungan $\mathrm{Hg}$ di perairan Muara Sungai Banyuasin bila dilihat dari 
KepMenLH No 51 No 2004, secara umum masih berada di batas maksimal ambang baku mutu $(0,001 \mathrm{mg} / \mathrm{L})$ untuk daerah yang dekat dengan mulut sungai dan di atas ambang baku mutu untuk daerah dekat dengan mulut muara. Hal ini perlu diwaspadai mengingat $\mathrm{Hg}$ mudah mengalami transformasi secara biologis dan berbahaya bagi organisme. Hal ini seperti yang ditegaskan Putranto (2011) Hg yang terdapat di perairan umum diubah oleh aktivitas mikroorganisme sehingga beracun dengan daya ikat dan kelarutan yang kuat disamping terutama dalam tubuh hewan air.

\section{Simpulan}

Hasil penelitian menunjukkan bahwa secara umum kualitas perairan di Muara Sungai Banyuasin masih memenuhi kriteria berdasarkan KepMenLH no 51 Tahun 2004 untuk baku mutu air laut bagi biota laut. konsetrasi logam $\mathrm{Hg}$ di perairan Muara Sungai Banyuasin berkisar antara 0.001-0.032 ppm dengan pola distribusi yang secara umum semakin meningkat kearah lautan. Konsentrasi Hg di Muara Sungai Banyuasin ratarata berada pada batas maksimal dan melampui baku mutu untuk biota laut.

\section{Ucapan terimakasih}

Penulis mengucapkan terima kasih kepada tim penelitian Siti Subaidah, Tonny Sepwiratama, Rico Febriansyah, dan Rama Adryan yang telah membantu dalam proses sampling dan analisis di laboratorium. Penulis juga mengucapkan terima kasih kepada reviewer atas masukan untuk perbaikan jurnal ini.

\section{Daftar Pustaka}

Achparaki, M., Thessalonikeos, E., Tsoukali, H., Mastrogianni, O., Zaggelidou, E., Chatzinikolaou, F., Vasilliades, N., \& Raikos, N. (2012). Heavy metals toxicity. Aristotle University Medical Journal, 39(1), 2934.

Affandi, K., Budiman, A., Candra, A., Yulia, M., Syawalina, Imansyah, T., Adiosyafri, Apriani, D., Wahyono, H., Catri, D. M., \& Pulungan, F. (2016). Perencanaan Tata Guna Lahan Untuk Mendukung Pembangunan Rendah Emisi di Kabupaten Banyuasin. Pangkalan Balai, Indonesia: Kelompok Kerja Perencanaan Tata Guna Lahan Mendukung Ekonomi Hijau dan Konservasi Biodiversitas (pokja PTGLEHKB) Kabupaten Banyuasin Provinsi Sumatera Selatan.
Ansyori, I. (2011). Pengendalian emisi merkuri di cerobong industri pada penggunaan batu bara sebagai bahan bakar. Jurnal Ecolab, 5(1), 15-19.

Bahnasawy, M., KHIDR, A. A., \& Dheina, N. (2011). Assessment of heavy metal concentrations in water, plankton, and fish of Lake Manzala, Egypt. Turkish Journal of Zoology, 35(2), 271-280.

Barus, B. S. (2017). Analisis kandungan logam berat kadmium $(\mathrm{Cd})$ dan merkuri $(\mathrm{Hg})$ pada air dan sedimen di perairan Muara Sungai Banyuasin. Maspari Journal, 9(1), 69-76.

Barkay, T., Gillman, M., \& Turner, R. R. (1997). Effects of dissolved organic carbon and salinity on bioavailability of mercury. Applied and Environmental Microbiology, 63(11), 4267-4271.

Biswas, P., Karn, A. K., Balasubramanian, P., \& Kale, P. G. (2017). Biosensor for detection of dissolved chromium in potable water: A review. Biosensors and Bioelectronics, 94, 589-604.

BPS Provinsi Sumatera Selatan. (2016). Provinsi Sumatera Selatan Dalam Angka 2016. Palembang, Indonesia: Badan Pusat Statistik Provinsi Sumatera Selatan.

Chen, C. W., Chen, C. F., \& Dong, C. D. (2012). Contamination and potential ecological of mercury in sediments of Kaohsiung river mouth, Taiwan. International Journal of Environmental Science and Development, 3(1), 66-71.

Hazliansyah. (2012). PT Pusri Ganti Alihkan Bahan Bakar Gas ke Batu Bara. [online] Tersedia di: https://www.republika.co.id/berita/nasional/umum/1 2/08/11/m8kq93-pt-pusri-ganti-alihkan-bahan-bakargas-ke-batu-bara, [diakses: 2 Oktober 2018].

Hutagalung, H. P. (1985). Raksa (Hg). Oseana, 10(3), 93105.

Jaishankar, M., Tseten, T., Anbalagan, N., Mathew, B. B., \& Beeregowda, K. N. (2014). Toxicity, mechanism and health effects of some heavy metals. Interdisciplinary Toxicology, 7(2), 60-72.

Kangkan, A. L. (2006). Studi penentuan lokasi untuk pengembangan budidaya laut berdasarkan parameter fisika, kimia dan biologi di Teluk Kupang, Nusa Tenggara Timur. Thesis. Semarang, Indenesia: Program Studi Magister Manajemen Sumberdaya Pantai, Prgra, Pascasarjana Universitas Diponegoro.

Kotas, J., \& Stasicka, Z. (2000). Chromium occurrence in the environment and methods of its speciation. Environmental Pollution, 107(3), 263-283. https://doi.org/10.1016/S0269-7491(99)00168-2.

Laporte, J. M., Truchot, J. P., Ribeyre, F., \& Boudou, A. (1997). Combined effects of water $\mathrm{pH}$ and salinity on the bioaccumulation of inorganic mercury and methylmercury in the shore crab Carcinus maenas. Marine Pollution Bulletin, 34(11), 880-893.

Lasut, M. T. (2009). Proses bioakumulasi dan biotransfer merkuri $(\mathrm{Hg})$ pada organisme perairan di dalam 
wadah terkontrol. Jurnal Matematika dan Sains, 14(3), 89-95.

Liu, N., Miao, Y., Zhou, X., Gan, Y., Liu, S., Wang, W., \& Dai, J. (2018). Roles of rhizospheric organic acids and microorganisms in mercury accumulation and translocation to different winter wheat cultivars. Agriculture, Ecosystems and Environment, 258, 104-112.

Lutfi, S. R., Wignyanto, \& Kurniati, E. (2018). Bioremediasi merkuri menggunakan bakteri indigenous dari limbah penambangan emas di Tumpang Pitu, Banyuwangi. Jurnal Teknologi Pertanian, 19(1), 15-24.

Neustadt, J., \& Pieczenik, S. (2007). Toxic-metal contamination: mercury. Integrative Medicine, 6(2), 2627.

Pawlikowski, M., Szalinska, E., Wardas, M., \& Dominik, J. (2006). Chromium originating from tanneries in river sediments: a preliminary investigation from the upper Dunajec River (Poland). Polish Journal of Environmental Studies, 15(6), 885-894.

Pramono, G. H. (2008). Akurasi metode IDW dan kriging untuk interpolasi sebaran sedimen tersuspensi. Forum Geografi, 22(1), 97-110.

Pratiwi, I. (2017). Analisis tingkat halangan produktivitas TLS II di PT. Bukit Asam (Persero) TBK. Journal Industrial Servicess, 3(1), 113-118.

Prasetio, H., Purwiyanto, A. I .S., \& Agussalim, A. (2016) Analisis logam berat timbal $(\mathrm{Pb})$ dan tembaga $(\mathrm{cu})$ dalam plankton di muara Banyuasin provinsi Sumatera Selatan. Maspari Journal, 8(2), 73-82.

Purnawan, S., Sikanna, R., \& Prismawiryanti. (2013). Distribusi logam merkuri pada sedimen laut di sekitar muara sungai Poboya. Online Jurnal of Natural Science, 2(1), 18-24.

Purwiyanto, A. I. S. (2015). Distribusi dan adsorpsi logam timbal $(\mathrm{Pb})$ di Muara Sungai Banyuasin, Sumatera Selatan. Indonesian Journal of Marine Sciences, 20(3), 153-162.

Purwiyanto A. I. S., Agustriani, F., Putri, W. A. E. \& Fauziyah. (2018). Water-air CO2 flux estimation in Banyuasin river estuary, South Sumatera Province, Indonesia. AES Bioflux, 10(2), 79-86.

Putranto, T. T. (2011). Pencemaran logam berat merkuri (Hg) pada air tanah. Teknik, 32(1), 62-71

Putri, W. A. E., Bengen, D. G., Prartono, T., Riani, E. (2016). Accumulation of Heavy Metals (Cu and $\mathrm{Pb}$ ) In Two Consumed Fishes from Musi River Estuary, South Sumatera. Indonesian Journal of Marine Sciences, 21(1), 45-52.

Ravichandran, M. (2004). Interactions between mercury and dissolved organic matter-a review. Chemosphere, 55(3), 319-331.

Regnell, O., Tunlid, A., Ewald, G., \& Sangfors, O. (1996). Methyl mercury production in freshwater microcosms affected by dissolved oxygen levels: role of cobalamin and microbial community composition. Canadian Journal of Fisheries and Aquatic Sciences, 53(7), 1535-1545.

Rusdianasari, R. (2015). Pemetaan kualitas udara di lingkungan stockpile batubara. In Prosiding Seminar Nasional Forum in Research, Science, and Technology (FIRST) 2015. Politeknik Negeri Sriwijaya, 27 Oktober 2015 (pp. 27-32)

Sari, S. H. J., Kirana, J. F. A., \& Guntur. 2017. Analisis kandungan logam berat $\mathrm{Hg}$ dan $\mathrm{Cu}$ terlarut di perairan pesisir Wonorejo, pantai timur Surabaya. Jurnal Pendidikan Geografi, 22(1), 1-9.

Schuhmacher, M., Domingo, J. L., Llobet, J. M., \& Corbella, J. (1993). Evaluation of the effect of temperature, $\mathrm{pH}$, and bioproduction on $\mathrm{Hg}$ concentration in sediments, water, molluscs and algae of the delta of the Ebro river. Science of the total environment, 134, 117-125.

Simanjuntak, M. (2009). Hubungan faktor lingkungan kimia, fisika terhadap distribusi plankton di perairan Belitung Timur, Bangka Belitung. Journal Fish Science, 11(1), 31-45.

Sembiring, S. M. R., Melki, \& Agustriani, F. (2012). Kualitas perairan muara Sungsang ditinjau dari konsentrasi bahan organik pada kondisi pasang surut. Maspari Journal, 4(2), 238-247.

Surbakti, H., Isnaini, \& Aryawati, R. (2014). Karakteristik massa air di perairan Muara Sungai Banyuasin. Dalam Prosiding Seminar Nasional MIPA 2014. Palembang, Indonesia, 2 Oktober 2014 (pp. 511-515).

Supriadi, I. H. (2001). Dinamika Estuari Tropik. Oseana, 26(4), 1-11.

Suteja, Y., \& Dirgayusa, I G. N. P. (2018). Bioaccumulation and translocation of chromium on crabs and mangroves in Mati River estuary, Bali, Indonesia. AACL Bioflux 11(2), 469-475.

Suyanto, A., Kusmiyati, S., \& Retnaningsih, C. (2010). Residu logam berat ikan dari perairan tercemar di pantai utara Jawa Tengah. Jurnal Pangan dan Gizi, 1(02), 33-38

Tilaar, S. (2014). Analisis pencemaran logam berat di muara sungai Tondano dan muara sungai Sario Manado Sulawesi Utara. Jurnal Ilmiah Platax, 2(1), 3239.

Toole-O'Neil, B., Tewalt, S. J., Finkelman, R. B., \& Akers, D. J. (1999). Mercury concentration in coalunraveling the puzzle. Fuel, 78(1), 47-54.

Ullrich, S. M., Tanton, T. W., \& Abdrashitova, S. A. (2001). Mercury in the aquatic environment: a review of factors affecting methylation. Critical reviews in environmental science and technology, 31(3), 241-293.

Ulqodry, T. Z., Bengen, D. G., \& Kaswadji, R. F. (2010). Karakteristik perairan mangrove Tanjung Api-api Sumatera Selatan berdasarkan sebaran parameter 
lingkungan perairan dengan menggunakan analisis komponen utama (PCA). Maspari Journal, 1(1), 16-21.

Zhang, L., \& Wong, M. H. (2007). Environmental mercury contamination in China: sources and impacts. Environment International, 33, 108-121.
Zulhaniarta, D., Fauziyah, Purwiyanto, A. I. S., \& Aryawati, R. (2015). Sebaran konsentrasi klorofil-a terhadap nutrien di Muara Sungai Banyuasin kabupaten Banyuasin provinsi Sumatera Selatan. Maspari Journal, 7(1), 9-20.

(C) 2018 by the authors; licensee Udayana University, Indonesia. This article is an open access article distributed under the terms and conditions of the Creative Commons Attribution license (http://creativecommons.org/licenses/by/3.0/). 